\title{
Micronutrient concentration of Italian ryegrass (Lolium multiflorum L.) grown on different soils in a pot experiment
}

\author{
RAIMO ERVIÖ and JOUKO SIPPOLA
}

ERVIŌ, R. \& SIPPOLA, J. 1993. Micronutrient concentration of Italian ryegrass (Lolium multiflorum L.) grown on different soils in a pot experiment. Agric. Sci. Finl. 2: 141-148. (Agric. Res. Centre, Inst. of Soils and Environment, FIN-31600 Jokioinen, Finland.)

The uptake of micronutrients, B, Co, Cu, Mn, Mo and $\mathrm{Zn}$, was studied in a pot experiment. The micronutrient concentrations of Italian ryegrass (Lolium multiflorum L.) ranged as follows: B 4.9-11.1, Co 0.01-2.30, Cu 2-15, Mn 29-225, Mo 0.01-1.79 and $\mathrm{Zn} 23-75 \mathrm{mg} \mathrm{kg}^{-1} \mathrm{DM}$. The micronutrient concentration of plant was compared with the AAAc+EDTA-extractable concentration in soil by soil type. The copper and zinc concentrations of ryegrass correlated stongly with the respective concentrations of all four soil type groups. The respective correlations of boron and manganese were good except in the silt soil group. Cobalt correlated best in coarse mineral and clay soils and molybdenum in clay and organic soils. Boron, cobalt, manganese and zinc concentrations of ryegrass were the higher the lower the soil $\mathrm{pH}$ was.

In the whole material the following correlations were found between the micronutrient concentrations of ryegrass and soil: boron $0.58^{* * *}$, cobalt $0.68^{* * * *}$, copper $0.70^{* * *}$, manganese $0.19^{* * *}$, molybdenum $0.69^{* * *}$ and zinc $0.90^{* * *}$. The results indicate that interpretation of micronutrient soil test data may be more accurate when soil type is considered.

Key words: Finnish soil types, AAAc+EDTA extraction, boron, cobalt, copper, manganese, molybdenum, zinc, micronutrient concentration

\section{Introduction}

Cultivated soils in Finland differ greatly of each other with regard to their genesis, texture and organic matter content. One fifth of Finnish cultivated soils are organic, and the coarsest mineral soils like sands and glacial tills remarkably differ from clay soils in nutrient cocentration and nutrient fixation. In routine soil testing and fertilizer recommendations concerning macronutrients, soils are classified into four main types based on the above properties. In micronutrient soil testing, at present, all soils are classified according to the same critical values. It is possible, however, that classification of soils might give a more accurate interpretation. Therefore more research on the micronutrient availability from Finnish soils is needed.

Italian ryegrass is a suitable crop for pot experiments and therefore a frequently used test crop. Its micronutrient requirement is, however, low like that of all grasses compared to dicotyledons. This may make ryegrass a less suitable crop in testing soils for micronutrient deficiencies in pot experiments.

The objective of this investigation was to study the growth of ryegrass on soils of low micronutrient 
Table 1. Mean soil characteristics (Ranges in parantheses).

\begin{tabular}{|c|c|c|c|c|c|c|c|c|c|c|c|}
\hline \multirow[t]{2}{*}{ Soil type group } & \multirow{2}{*}{$\begin{array}{l}\text { No of } \\
\text { samples }\end{array}$} & \multirow{2}{*}{$\mathrm{pH}\left(\mathrm{H}_{2} \mathrm{O}\right)$} & \multirow{2}{*}{$\begin{array}{c}\text { Org. C } \\
\%\end{array}$} & \multicolumn{3}{|c|}{ Particle size distribution } & \multirow{2}{*}{$\begin{array}{c}\text { CEC } 1 \text { ) } \\
\text { me } 100 \mathrm{~g}^{-1} \\
\text { soil }\end{array}$} & \multicolumn{4}{|c|}{ AAAc-extractable elements $\mathrm{mg} \mathrm{l}^{-1}$ soil } \\
\hline & & & & $\begin{array}{c}\text { clay } \\
<0.002 \\
\mathrm{~mm}\end{array}$ & $\begin{array}{c}\text { silt } \\
0.002-0.02 \\
\mathrm{~mm}\end{array}$ & $\begin{array}{c}\text { coarse } \\
>0,02 \\
\mathrm{~mm}\end{array}$ & & $\mathrm{Ca}$ & K & $\mathrm{Mg}$ & $\mathbf{P}$ \\
\hline Finesand and till & 28 & $\begin{array}{c}5.70 \\
(5.0-6.5)\end{array}$ & $\begin{array}{c}3.66 \\
(1.8-5.4)\end{array}$ & $\begin{array}{c}6 \\
(0-28)\end{array}$ & $\begin{array}{c}17 \\
(0-39)\end{array}$ & $\begin{array}{c}77 \\
(37-100)\end{array}$ & $\begin{array}{l}15.0 \\
(8-29)\end{array}$ & 900 & 75 & 80 & 7.6 \\
\hline Silt & 11 & $\begin{array}{c}6.05 \\
(5.6-6.5)\end{array}$ & $\begin{array}{c}2.59 \\
(1.6-4.3)\end{array}$ & $\begin{array}{c}20 \\
(10-29)\end{array}$ & $\begin{array}{c}49 \\
(43-60)\end{array}$ & $\begin{array}{c}31 \\
(10-45)\end{array}$ & $\begin{array}{c}15.7 \\
(11-24)\end{array}$ & 1043 & 101 & 129 & 7.8 \\
\hline Clay & 16 & $\begin{array}{c}5.73 \\
(5.2-6.2)\end{array}$ & $\begin{array}{c}3.15 \\
(1.6-4.3)\end{array}$ & $\begin{array}{c}47 \\
(32-66)\end{array}$ & $\begin{array}{c}32 \\
(16-47)\end{array}$ & $\begin{array}{c}21 \\
(12-51)\end{array}$ & $\begin{array}{l}24.0 \\
(16-36)\end{array}$ & 1453 & 208 & 374 & 6.3 . \\
\hline Organic soils & 19 & $\begin{array}{c}5.10 \\
(4.3-6.1)\end{array}$ & $\begin{array}{c}30.4 \\
(13-49)\end{array}$ & - & - & - & $\begin{array}{c}74.0 \\
(39-112)\end{array}$ & 2006 & 73 & 228 & 12.6 \\
\hline
\end{tabular}

1) = potential cation exchange capacity

Table 2. Mean extractable micronutrient concentrations of different soil types. (Ranges in parantheses.)

\begin{tabular}{|c|c|c|c|c|c|c|c|}
\hline \multirow[t]{2}{*}{ Soil type group } & \multirow{2}{*}{$\begin{array}{l}\text { No of } \\
\text { samples }\end{array}$} & \multirow[t]{2}{*}{. } & \multicolumn{5}{|c|}{ AAAc + EDTA extractable elements $\mathrm{mg} \mathrm{l}^{-1}$ soil } \\
\hline & & & Co & $\mathrm{Cu}$ & Mn & Mo & $\mathrm{Zn}$ \\
\hline Fine sand and till & 28 & $\begin{array}{c}0.48 \\
(0.25-1.19)\end{array}$ & $\begin{array}{c}0.52 \\
(0.12-1.35)\end{array}$ & $\begin{array}{c}1.6 \\
(0.5-5.6)\end{array}$ & $\begin{array}{c}71 \\
(8-220)\end{array}$ & $\begin{array}{c}0.04 \\
(0.01-.17)\end{array}$ & $\begin{array}{c}6.7 \\
(0.6-26.4)\end{array}$ \\
\hline Silt & 11 & $\begin{array}{c}0.36 \\
(0.16-.60)\end{array}$ & $\begin{array}{c}1.35 \\
(0.60-1.95)\end{array}$ & $\begin{array}{c}2.1 \\
(1.0-5.6)\end{array}$ & $\begin{array}{c}131 \\
(28-322)\end{array}$ & $\begin{array}{c}0.04 \\
(0.00-.12)\end{array}$ & $\begin{array}{c}2.5 \\
(1.0-6.3)\end{array}$ \\
\hline Clay & 16 & $\begin{array}{c}0.52 \\
(0.20-.74)\end{array}$ & $\begin{array}{c}2.66 \\
(0.40-7.0)\end{array}$ & $\begin{array}{c}7.0 \\
(1.3-18.7)\end{array}$ & $\begin{array}{c}72 \\
(9-180)\end{array}$ & $\begin{array}{c}0.35 \\
(0.00-1.5)\end{array}$ & $\begin{array}{c}8.2 \\
(1.1-27.0)\end{array}$ \\
\hline Organic soils & 19 & $\begin{array}{c}0.76 \\
(0.30-1.20)\end{array}$ & $\begin{array}{c}0.77 \\
(0.15-1.35)\end{array}$ & $\begin{array}{c}3.8 \\
(0.4-9.6)\end{array}$ & $\begin{array}{c}45 \\
(2-124)\end{array}$ & $\begin{array}{c}0.10 \\
(0.04-.57)\end{array}$ & $\begin{array}{c}6.9 \\
(2.0-25.5)\end{array}$ \\
\hline
\end{tabular}

status, to quantify the uptake of micronutrients and to study the effect of soil types and some factors such as $\mathrm{pH}$, organic carbon and extractable calcium concentration on the uptake.

\section{Material and methods}

Soil samples were collected from the plough layer of cultivated fields from 74 sites for a pot experiment. The samples represented typical arable Finnish soil types according to their micronutrient concentration (Tables 1 and 2). The relatively low pH and macronutrient concentrations of the soils were corrected before homogenizetion of soils by additional fertilization $(\mathrm{Ca}, \mathrm{Mg}, \mathrm{K}, \mathrm{P})$ to avoid deficiency in this respect. The soil concentrations in
Table 1 were measured after addition of the nutrients.

The experimental soils were homogenized and passed through a 2-mm sieve. Polyethylene KickBraukmann type pots and 7.51 of soil were used. The test were made in triplicate. Soils were fertilized before sowing with $0.2 \mathrm{~g}$ nitrogen as $\mathrm{NH}_{4} \mathrm{NO}_{3}$, $0.5 \mathrm{~g}$ potassium as $\mathrm{K}_{2} \mathrm{SO}_{4}$ and $0.1 \mathrm{~g}$ phosphorus as $\mathrm{Ca}\left(\mathrm{H}_{2} \mathrm{PO}_{4}\right)_{2} \mathrm{H}_{2} \mathrm{O}$ per 11 soil.

Italian ryegrass (Lolium multiflorum, cvs. Avance) was sown on 17 May, 1982 and grown outdoors. After emergence, each pot was thinned to 60 seedlings. Watering to $70 \%$ of field capacity was done twice a week. Pots were harvested just before the emergence of the ear. The first harvest was cut at 42 days and the second harvest 17 days later. Macro- and microelement concentrations of rye- 
Table 3. Mean micronutrient concentrations of ryegrass grown on different soil types at first harvest. (Ranges in parantheses.)

\begin{tabular}{|c|c|c|c|c|c|c|c|}
\hline \multirow[t]{2}{*}{ Soil type group } & \multirow{2}{*}{$\begin{array}{l}\text { No. of } \\
\text { samples }\end{array}$} & \multicolumn{6}{|c|}{$\mathrm{mg} \mathrm{kg}^{-1} \mathrm{DM}$} \\
\hline & & B & Co & $\mathrm{Cu}$ & $\mathrm{Mn}$ & Mo & $\mathrm{Zn}$ \\
\hline Fine sand and till & 28 & $\begin{array}{c}7.9 \\
(5.8-11.1)\end{array}$ & $\begin{array}{c}0.11 \\
(0.01-.53)\end{array}$ & $\begin{array}{c}6.0 \\
(3-12)\end{array}$ & $\begin{array}{c}84 \\
(49-157)\end{array}$ & $\begin{array}{c}0.10 \\
(0.02-.52)\end{array}$ & $\begin{array}{c}41 \\
(23-74)\end{array}$ \\
\hline Silt & 11 & $\begin{array}{c}7.5 \\
(5.4-9.3)\end{array}$ & $\begin{array}{c}0.16 \\
(0.01-.51)\end{array}$ & $\begin{array}{c}8.2 \\
(5-11)\end{array}$ & $\begin{array}{c}98 \\
(29-225)\end{array}$ & $\begin{array}{c}0.10 \\
(0.03-.27)\end{array}$ & $\begin{array}{c}36 \\
(26-43)\end{array}$ \\
\hline Clay & 16 & $\begin{array}{c}7.5 \\
(4.9-8.7)\end{array}$ & $\begin{array}{c}0.47 \\
(0.01-2.30)\end{array}$ & $\begin{array}{c}10.2 \\
(6-15)\end{array}$ & $\begin{array}{c}79 \\
(46-122)\end{array}$ & $\begin{array}{c}0.27 \\
(0.02-.87)\end{array}$ & $\begin{array}{c}42 \\
(27-75)\end{array}$ \\
\hline Organic soils & 19 & $\begin{array}{c}8.5 \\
(6.0-11.0)\end{array}$ & $\begin{array}{c}0.16 \\
(0.03-.41)\end{array}$ & $\begin{array}{c}6.7 \\
(2-10)\end{array}$ & $\begin{array}{c}80 \\
(37-116)\end{array}$ & $\begin{array}{c}0.27 \\
(0.01-1.79)\end{array}$ & $\begin{array}{c}39 \\
(29-48)\end{array}$ \\
\hline
\end{tabular}

grass were determined after dry ashing by atomic absorption, except for boron which was analysed using azomethine-H reagent. For soil analysis, representative samples of each soil were air dried and passed through a $2-\mathrm{mm}$ sieve. The $\mathrm{pH}$ was measured from a soil water suspension (1:2.5). Organic carbon content was determined by the dry-combustion method with a LECO CR-12 instrument. Cobalt, copper, manganese, molybdenum and zinc were extracted from soils using a $0.02 \mathrm{M}$ EDTA + $0,5 \mathrm{~N}$ ammoniumacetate and $0.5 \mathrm{~N}$ acetic acid solution (LAKANEN and ERVIÖ 1971), and calcium and other macroelements using AAAc solution (VUORINEN and MÄKITIE 1955). The extraction ratio was $1: 10 \mathrm{v} / \mathrm{v}$ and extractiontime $1 \mathrm{~h}$. Micronutrient centrations were determined by atomic absorption spectrophotometry using an air acetylene flame except for cobalt and molybdenum which were analysed in a graphite furnace. Boron was determined by the azomethine-H method after hot water extraction.

\section{Results and discussion}

The trace element concentration of a plant growing poorly does not always indicate the concentration of micronutrient available in soil; total uptake would be a better index. However, in cases where micronutrient concentration does not affect the yield the concentration may be an equally good indicator. Italian ryegrass grew in all experimental soils well without any symptoms of deficiency. The yields ranged within narrow limits from 4.52 to
$4.76 \mathrm{~g} / \mathrm{pot}$ except the one soil (sandy till) which yielded only $2.77 \mathrm{~g} /$ pot. Therefore total uptake was not calculated; the evaluation of results was based on nutrient concentrations.

The mean macronutrient concentrations and ranges in ryegrass dry matter were as follows: calcium $0.39 \%(0.27-0.51)$, potassium $6.0 \%$ (4.35$7.44)$, magnesium $0.20 \%(0.10-0.29)$ and phosphorus $0.45 \%(0.18-0.87)$. These values were within normal ranges, except for potassium which was rather high. So a deficiency in macronutrients was not expected to affect the micronutrient absorption.

The potassium concentrations of ryegrass differed least between the soil type groups apparently due to the ample dose given as fertilizer. Ryegrass grown on coarse mineral soils contained less than average magnesium and phosphorus. On clay soils ryegrass contained more than average magnesium and on organic soils less calcium but more phosphorus than the material on average.

$\mathrm{Ca}, \mathrm{Mg}$ and $\mathrm{P}$ concentrations of ryegrass very significantly correlated with their AAAc-extractable concentrations in soil $\left(\mathrm{Ca}: \mathrm{R}=0.25^{* * *}, \mathrm{Mg}\right.$ : $\mathrm{R}=0.77^{* * *}$ and $\mathrm{P}: \mathrm{R}=0.75^{* * * *}$ ). Exept the group of silt soils, significant correlations were observed also in the case of potassium.

\section{Micronutrient concentrations of ryegrass}

In general, the differences were relatively small in the micronutrient concentrations of ryegrass grown on different soil types (Table 3 ). The group of clay 
Table 4. Correlation coefficients between micronutrient concentrations in the ryegrass of first (I) and second (II) harvest and water-extractable B and AAAc + EDTA -extractable $\mathrm{Co}, \mathrm{Cu}, \mathrm{Mn}, \mathrm{Mo}$, and $\mathrm{Zn}$ in soil.

\begin{tabular}{|c|c|c|c|c|c|c|c|c|}
\hline \multirow[t]{2}{*}{ Soil type group } & \multirow[t]{2}{*}{ Harvest } & \multirow{2}{*}{$\begin{array}{l}\text { No. of } \\
\text { samples }\end{array}$} & \multicolumn{6}{|c|}{ Micronutrient } \\
\hline & & & B & Co & $\mathrm{Cu}$ & Mn & Mo & $\mathrm{Zn}$ \\
\hline Fine sand and till & $\begin{array}{r}\text { I } \\
\text { II }\end{array}$ & 28 & $\begin{array}{l}0.65^{* *} \\
0.56^{* *}\end{array}$ & $\begin{array}{l}0.64^{* *} \\
0.61\end{array}$ & $\begin{array}{l}0.57^{* \cdots} \\
0.57^{* * *}\end{array}$ & $\begin{array}{l}0.34^{* *} \\
0.33^{*}\end{array}$ & - & $\begin{array}{l}0.94 \cdots \\
0.84\end{array}$ \\
\hline Silt & $\begin{array}{l}\text { I } \\
\text { II }\end{array}$ & 11 & $0.51^{-*}$ & - & $\begin{array}{l}0.65^{* * *} \\
0.70^{* * *}\end{array}$ & - & $0.63^{-\cdots}$ & $\begin{array}{l}0.70^{* *} \\
0.51 *\end{array}$ \\
\hline Clay & $\begin{array}{r}\text { I } \\
\text { II }\end{array}$ & 16 & $\begin{array}{l}0.56^{* *} \\
0.48^{*}\end{array}$ & $\begin{array}{l}0.63^{\cdots *} \\
0.70^{\cdots *}\end{array}$ & $\begin{array}{l}0.83^{\cdots *} \\
0.88^{* *}\end{array}$ & $\begin{array}{l}0.51^{\cdots *} \\
0.52 \cdots\end{array}$ & $\begin{array}{l}0.90^{* *} \\
0.94^{\cdots *}\end{array}$ & $\begin{array}{l}0.97 \cdots \\
0.96 * \cdots\end{array}$ \\
\hline Organic soils & $\begin{array}{l}\text { I } \\
\text { II }\end{array}$ & 19 & $\begin{array}{l}0.53^{\cdots} \cdots \\
0.46\end{array}$ & - & $\begin{array}{l}0.79 \cdots \\
0.82 \cdots\end{array}$ & $\begin{array}{l}0.60^{*} \cdots \\
0.61\end{array}$ & $\begin{array}{l}0.77^{\cdots} \cdots \\
0.85^{\cdots}\end{array}$ & $\begin{array}{l}0.72 \cdots \\
0.59 \cdots\end{array}$ \\
\hline All soils & $\begin{array}{r}\text { I } \\
\text { II }\end{array}$ & 74 & $\begin{array}{l}0.58^{* \cdots} \\
0.57^{* *}\end{array}$ & $\begin{array}{l}0.68^{* * *} \\
0.71 * *\end{array}$ & $\begin{array}{l}0.70^{* \cdots} \\
0.80^{* *}\end{array}$ & $\begin{array}{l}0.19^{* *} \\
0.17^{* *}\end{array}$ & $\begin{array}{l}0.69^{* *} \\
0.81^{* *}\end{array}$ & $\begin{array}{l}0.90^{* *} \\
0.81 \cdots\end{array}$ \\
\hline
\end{tabular}

t-test: ${ }^{\cdots} \mathrm{P}=<0.001,{ }^{\cdots}=\mathrm{P}<0.01$

soils included four expe-rimental soils which had earlier been fertilized with micronutrients. Accordingly, fertilized soils raised the mean and maximum soil concentration, especially those of cobalt and molybdenum (Table 2). Even if the fertilized soils were excluded the mean cobalt value $\left(0.26 \mathrm{mg} \mathrm{l}^{-1}\right)$ of ryegrass would be higher than those of other soils, while the mean molybdenum concentration $\left(0.09 \mathrm{mg} \mathrm{l}^{-1}\right)$ would be within the same range with other unfertilized mineral soils.

\section{Correlation of plant nutrient concentrations with that in soil and with some soil properties}

\section{Boron}

The boron concentration of ryegrass correlated very well with the hot water-extractable soil boron in the groups of coarse mineral soils, clays and organic soils (Table 4). This correlation did not exist in the group of silt soils in the first harvest, which may be due to the limited number of experimental soils.

The boron concentration of ryegrass was found to correlate positively with soil organic carbon in the whole material (Table 5) as has been observed previously in grasses (TOLGYESI and KOZMA 1974). This is understandable because the concen- tration of water soluble-boron in soil increases with increasing organic matter (GUPTA 1978). In the whole material the boron concentration of ryegrass correlated slightly negatively with soil $\mathrm{pH}$. TOLGYESI and KOZMA (1974) found the same with grasses. SILLANPÄÄ (1982) showed that soil pH had a relatively small effect on boron in plant at a slightly acid pH level, which was confirmed also by the present results.

\section{Cobalt}

The cobalt concentration of ryegrass grown on fine sand and clay soils very significantly correlated with soil-extractable cobalt, but no correlation was observed in the groups of silt and organic soils. The soil $\mathrm{pH}$ reflected in the ryegrass cobalt concentration; with increasing $\mathrm{pH}$ the cobalt concentration of first harvest decreased only in the groups of silt and organic soils. In the second harvest this negative correlation was observed the whole material and all soil type groups. A similar negative correlation between the cobalt concentration of ryegrass and soil $\mathrm{pH}$ has been observed earlier in some studies (COPPENET et al. 1972, PATERSON et al. 1989). Inversely, Mokragnatz and FILIPOVIC (1961) and McLAREN et al. (1987), showed an increase in the cobalt concentration of leygrass with increasing soil $\mathrm{pH}$. 
Table 5. Correlation coefficients between soil $\mathrm{pH}\left(\mathrm{H}_{2} \mathrm{O}\right)$, extractable $\mathrm{Ca}$, organic carbon content and micronutrient concentration in ryegrass.

\begin{tabular}{|c|c|c|c|c|c|c|c|c|}
\hline & & \multirow[t]{2}{*}{ No } & \multicolumn{2}{|c|}{$\mathrm{pH}$} & \multicolumn{2}{|c|}{ Extractable calcium } & \multicolumn{2}{|c|}{ Organic carbon content } \\
\hline & & & 1st harvest & 2nd harvest & 1st harvest & 2nd harvest & 1st harvest & 2nd harvest \\
\hline \multirow[t]{5}{*}{ Boron } & 1 Finesand, till & 28 & $0.22^{\circ}$ & $.19^{*}$ & $0.26^{\circ *}$ & - & - & - \\
\hline & 2 Silt & 11 & - & - & - & - & $-0.31^{*}$ & - \\
\hline & 3 Clay & 16 & - & $-.39^{* *}$ & - & - & - & - \\
\hline & 4 Organic soil & 19 & - & - & - & - & - & \\
\hline & 5 All soils & 74 & $-0.14^{*}$ & $-0.18^{* *}$ & $0.17^{* *}$ & - & $0.25^{\cdots *}$ & $0.23^{* \cdots}$ \\
\hline \multirow[t]{5}{*}{ Cobalt } & 1 Finesand, till & & - & $-0.25^{\circ}$ & - & - & $-0.26^{* *}$ & $-0.21^{*}$ \\
\hline & 2 Silt & & $-0.59^{* * *}$ & $-0.67^{* * *}$ & $-0.47^{* *}$ & $-0.55^{* \cdots}$ & $-0.39^{*}$ & - \\
\hline & 3 Clay & & - & $-0.29^{\circ}$ & $0.54^{* * *}$ & $0.50^{* * *}$ & $0.62^{* * *}$ & $0.62^{* * *}$ \\
\hline & 4 Organic soil & & $-0.32^{* *}$ & $-0.58^{* * *}$ & - & $-0.48^{\cdots *}$ & - & - \\
\hline & 5 All soils & & - & $-0.16^{* *}$ & $0.18^{* *}$ & $0.13^{*}$ & - & - \\
\hline \multirow[t]{5}{*}{ Copper } & 1 Finesand, till & & - & - & - & - & - & - \\
\hline & 2 Silt & & $-0.37^{*}$ & $-0.38^{\circ}$ & - & - & $0.36^{\circ}$ & $0.42^{* *}$ \\
\hline & 3 Clay & & - & $-0.30^{\circ}$ & - & $0.25^{\circ}$ & - & $0.25^{*}$ \\
\hline & 4 Organic soil & & - & $0.27^{*}$ & $0.40^{* * *}$ & $0.44^{* * *}$ & - & - \\
\hline & 5 All soils & & - & - & $0.22^{* * *}$ & $0.14^{*}$ & $-0.19^{* *}$ & $-0.25^{* * *}$ \\
\hline \multirow[t]{5}{*}{ Manganese } & 1 Finesand, till & & $-0.53^{* * *}$ & $-0.72^{* *}$ & $-0.37^{* * *}$ & $-0.43^{\cdots \cdot}$ & $-0.24^{*}$ & - \\
\hline & 2 Silt & & $-0.69^{* * *}$ & $-0.76^{* * *}$ & $-0.64^{* * *}$ & $-0.66^{* * *}$ & $-0.34^{*}$ & - \\
\hline & 3 Clay & & $-0.25^{\circ}$ & $-0.42^{* * *}$ & - & - & $0.29^{*}$ & $-0.33^{* *}$ \\
\hline & 4 Organic soil & & - & - & - & - & $-0.32^{* *}$ & $-0.34^{* *}$ \\
\hline & 5 All soils & & $-0.14^{*}$ & $-0.28^{* * *}$ & $-0.19^{* *}$ & $-0.19^{* *}$ & $-0.12^{*}$ & - \\
\hline \multirow[t]{5}{*}{ Molybdenum } & 1 Finesand, till & & - & - &.- & - & - & - \\
\hline & 2 Silt & & $0.59^{* * *}$ & - & $0.48^{* *}$ & - & - & - \\
\hline & 3 Clay & & - & - & $0.39^{* *}$ & $0.46^{* * *}$ & $0.27^{*}$ & $0.42^{* * *}$ \\
\hline & 4 Organic soil & & $0.33^{* *}$ & $-0.29^{*}$ & $0.63^{* * *}$ & $0.71^{* * *}$ & - & - \\
\hline & 5 All soils & & - & - & $0.50^{* * *}$ & $0.53^{* * *}$ & $0.12^{\circ}$ & $0.12^{\circ}$ \\
\hline \multirow[t]{5}{*}{ Zinc } & 1 Finesand, till & & - & $-0.26^{* *}$ & - & - & $0.21^{\circ}$ & $0.23^{*}$ \\
\hline & 2 Silt & & $-0.41^{\circ}$ & $-0.62^{* * *}$ & - & $-0.44^{* *}$ & $0.48^{* *}$ & $0.35^{\circ}$ \\
\hline & 3 Clay & & - & $-0.30^{\circ}$ & $0.32^{\circ}$ & - & - & $0.23^{\circ}$ \\
\hline & 4 Organic soil & & - & - & $0.44^{* *}$ & - & - & - \\
\hline & 5 All soils & & - & $-0.14^{*}$ & $0.14^{\circ}$ & - & - & $-0.14^{*}$ \\
\hline
\end{tabular}

t-test: ${ }^{\cdots}=\mathrm{P}<0.001,{ }^{*}=\mathrm{P}<0.01,{ }^{*}=\mathrm{P}<0.05$

\section{Copper}

The copper concentration of ryegrass correlated very significantly with extractable copper in all soil type groups. The correlation was closest in the groups of clay $\left(\mathrm{r}=0.88^{* * * *}\right)$ and organic $\left(\mathrm{r}=0.82^{* * * *}\right)$ soils of the second harvest. KIEKENS and COTTENIE
(1983) found also a relatively good correlation between ryegrass and soil AAAc-EDTAextractable copper $\left(\mathrm{r}=0.40^{* *}\right)$. The copper has generally been shown to be fixed into a nonsoluble form by soil organic matter (e.g. BROADBENT and OTT 1957). In the whole material a significant negative correlation was found between copper concentration of 
ryegrass and soil organic carbon. A similar dependence of $\mathrm{Cu}$ concentration between wheat straw and soil has been reported also by SILLANPÄÄ (1982) in a material including Finnish soils and by LUIT and HENKENS (1967) with ryegrass.

With increasing extractable calcium also the copper concentration of ryegrass increased in the whole material and especially in organic soils. With soil $\mathrm{pH}$ no dependence was found in the whole material. BROWN and JURINAK (1964) could not increase the copper concentration of corn by addition of Ca. BEYME (1971) obtained a negative correlation between copper concentration of oats and soil pH, but LuIT and HENKENS (1967) did not report this kind of correlation in peat soil.

\section{Manganese}

The manganese concentration of ryegrass correlated with soil extractable concentrations in all soil groups exept for silt soils. The exceptional result for silt soils may be due to the higher $\mathrm{pH}$ range in this group which limits the availability of manganese. Using the same extraction solution KIEKENS and COTTENIE (1983) obtained in a pot experiment with a material of 52 soils collected from several countries a negative correlation $\left(r=-0.34^{*}\right)$. They reported that the most important parameter affecting the uptake of manganese by perennial ryegrass was soil $\mathrm{pH}$. In the present material a negative correlation was found with manganese concentration of ryegrass and the extractable $\mathrm{Ca}$ concentration of soil in the whole material as well as in finesand and silt soil groups.

In the whole material a negative correlation was obtained between manganese concentration of ryegrass and soil $\mathrm{pH}$. This relation was most evident in the groups of finesand and silt soils, and no correlation existed in the group of organic soils. This relationship for grasses has long been known (PIPER 1931, STEEnbJerg 1933, Olsen 1934). Also SILLANPÄÄ (1982) obtained in a large international soil material a clear negative correlation between manganese concentration of wheat and soil $\mathrm{pH}$. He considered the effect on manganese so important that he suggested a correction factor based on soil $\mathrm{pH}$ for the manganese soil test value.

\section{Molybdenum}

The molybdenum concentration of ryegrass correlated highly significantly with soil concentrations in the groups of clay and organic soils, but no correlation was observed in groups of finesand and silt soils in the first harvest.

The molybdenum concentration of ryegrass was high when also the soil extractable calcium concentration was high $\left(\mathrm{r}=0.50^{* * *}\right)$ in the whole material. The correlation was especially close in the group of organic soils $\left(\mathrm{r}=0.63^{* * *}\right)$. This dependence has been observed in many studies (PLANT 1950, GUPTA 1969, JAAKKOLA 1972).

In the whole material ryegrass molybdenum concentration did not correlate with soil $\mathrm{pH}$ although in many studies a positive dependence has been observed (BARSHAD 1951, KARLSSON 1961). In the groups of silt and organic soils of the present study this positive dependence was observed in the first harvest.

\section{Zinc}

The zinc concentration of ryegrass correlated better than any other micronutrient with soil-extractable zinc in this study. The closest correlation occured in the group of clay soils $\left(r=0.97^{* * *}\right)$ followed by finesand soils $\left(\mathrm{r}=0.94^{* * * *}\right)$. A rather close correlation was observed also by KIEKENS and COTTENIE (1983) between ryegrass zinc and AAAc-EDTAextractable soil zinc.

The increase of extractable calcium in soil also led to an increase of ryegrass zinc in the first harvest. This correlation was closest in the group of organic soils $\left(\mathrm{r}=0.44^{* * *}\right)$. The result disagrees with some earlier results where liming decreased the zinc concentration of cereal grains (WEAR 1956). The zinc concentration of ryegrass did not correlate with soil $\mathrm{pH}$ in the whole material, but a negative correlation was found in the group of silt soils. Also SILLANPÄÄ (1982) reported a negative correlation between $\mathrm{Zn}$ concentration of wheat straw and soil $\mathrm{pH}$.

The results show that there were differences between soil types in the availability of micronutrients to ryegrass. The uptake of cobalt from organic 
soils, for example, was similar to silt soils despite a twice as high extractable cocentration in silt soils. Also the uptake of copper from finesand and silt was almost equal to the uptake from other soils despite low soil concentration. Therefore it is obvious that the interpretation of micronutrient soil test results is more accurate when soil type is considered.

\section{References}

BARSHAD, I. 1951. Factors affecting the molybdenum content of pasture plants: I. Nature of soils molybdenum, crowth of plants and soil pH. Soil Sci. 71: 297-313.

BeYme, G. 1971. Beziehungen zwischen Zink- und Kupfergehalt in Haferpflanzen und Böden. Z. Pfl.ernähr. Bodenkunde 130: 256-270.

Broadbent, F. E. \& OTt, J. B. 1957. Soil organic mattermetal complexes: 1 . Factors affecting retention of various cations. Soil Sci. 83: 419-427.

Brown, A. L. \& JurinaK, J. J. 1964. Effect of liming on the availabilities on zinc and copper. Soil Sci. 98: 170-173.

Coppenet, M., More, E., Le Corre, L. \& Le Mao, M. 1972. Variations de la leneur en cobalt des ray-grass de techniques d'enrichissement. Ann. Agron. 23: 165-196.

GuptA, C. 1969. Effect and interaction of molybdenum and limestone on growth and molybdenum content of cauliflower, alfalta and bromegrass on acid soils. Soil Sci. Soc. Proc. 33: 929-932.

- 1978. Effect of soil properties on the extractable boron contents. Schweiz. Landw. Forsch. 17: 45-50.

JAAKKOLA, A. 1972. Availability to plants of molybdenum in Finnish mineral soils. Acta Agr. Fenn. 120: 1-92.

KARLSSON, N. 1961. Om molybden i svensk vegetation och mark samt några därmed sammanhängande frågor. Summary: On molybdenum in Swedish soil and vegetation and some related questions. Statens Lantbrukskem. kontrollanst. Medd. 23: 1-243.

Kiekens, L. \& Cottenie, A. 1983. Estimation of trace element status by chemical soil and plant analyses. Rep. 1983 consult. Eur. Cooper. Network Trace Elements. Aarhus.

LAKanen, E. \& Erviö, R. 1971. A comparison of eight extractants for the determination of plant available micronutrients in soils. Acta Agr. Fenn. 123: 223-232.

Lurr, B. van \& Henkens, C. H. 1967. The effect of the copper status of the soil on the copper content of grass and clover. Vevsl. Landbouwk. Ouderz. 695. 33 p.

Mclaren, R. G., Lawson, D. M. \& Swift, R. S. 1987. The availability to pasture plants native and applied soil cobalt and other soil properties. J. Sci. Food Agric. 39: 101-112.
MokragnatZ, M. \& Filipovic, Z. 1961. Further evidence of the influence of soil $\mathrm{pH}$ on cobalt contents of grasses. Soil Sci. 92: 127-128.

OlsEn, C. 1934. Uber die Manganaufnahme der Pflanzen. Biockem. Z. 269: 329-348.

PARK, C. S. \& PARK, N. J. 1966. The available boron content in soils of the upland crop area of Korea. Agric. For., Korea 9: 163-174.

Paterson, J. E., Klessa, D. A. \& MacPherson, A. 1989. Factors influencing the availability of soil cobalt and its uptake by herbage. 16. Int. Grassland Congr. Nice, France Proc. p. 19-20.

PIPER, C. S. 1931. The availability of manganese in the soil. J. Agr. Sci. 21: 762-779.

Plant, W. 1950. The relation of molybdenum deficiency to the acid soil complex. Transact. 4 th Int. Congr. Soil Sci. 2: 148-151.

SILLANPÄÄ, M. 1982. Micronutrients and the nutrient status of soils: a global study. FAO Soils Bull. 48. 444 p.

STEENBJERG, F. 1933. Undersogelser over manganinholdet in dansk jord. I. Det ombyttelige mangan. Tidskr. Planteavl. 39: 401-436.

TölgYesı, G. \& KozmA, A. 1974. A pázsitfüvek bórfelvételét befolyásoló tényezók. Summary: Investigation on factors affecting boron uptake by grasses. Agrokem. Talajtan 23: 83-98.

VuORINEN, J. \& MÄKITIE, O. 1955. The method of soil testing in use in Finland. Agrogeol. Publ. 63: 1-44.

WEAR, J. J. 1956. Effect of soil $\mathrm{pH}$ and calcium on uptake of zinc by plants. Soil Sci. 81: 311-315.

Manuscript received January 1993

Raimo Erviö

Jouko Sippola

Agricultural Research Centre of Finland

Institute of Soils and Environment

FIN-31600 Jokioinen, Finland 
SELOSTUS

\title{
Italianraiheinän hivenravinteiden otto vaihtelevan määrän näitä ravinteita sisältävistä erilaisista maalajeista
}

\author{
RAIMO ERVIÖ ja JOUKO SIPPOLA
}

Maatalouden tutkimuskeskus

Ulkona tehdyssä astiakokeessa Jokioisilla tutkittiin Italianraiheinän (Lolium multiflorum L.) hivenravinteiden boorin, koboltin,kuparin, mangaanin, molybdeenin ja sinkin ottoa 74 maaerästä, jotka olivat kyntökerroksesta ja joiden hivenravinnetaso vaihteli. Maaerien $\mathrm{pH}$-arvot, pääravinteiden pitoisuudet ja humuspitoisuudet olivat maalajeille ominaista keskimääräistä tasoa. Maat ryhmiteltiin hietoihin ja moreeneihin, hiesuihin, saviin ja turve- sekä multamaihin.

Raiheinän hivenravinteiden vaatimustaso on alhainen, ja heinä kasvoi normaalisti yhtä maata lukuun ottamatta kaikilla koemailla, joilla se myös antoi melko samantasoisen kuiva-ainesadon.

Raiheinän hivenravinnepitoisuuksia verrattiin liukoisiin pitoisuuksiin koemaissa kokeen alkaessa. Sekä ensimmäisen että toisen sadon raiheinän pitoisuuksien riippuvuudet tutkittiin. Koko aineistosta saatiin raiheinän boorin, koboltin, kuparin, molybdeenin ja sinkin pitoisuuksille erittäin merkitsevä ja mangaanille hyvin merkitsevä riippuvuus maan helppoliukoisten vastaavien hivenravinteiden pitoisuuksista. Kummankaan sadon hivenravinteiden merkitsevää riippuvuutta ei todettu hiesumailla koboltin eikä mangaanin suhteen eikä myöskään hieta- mailla molybdeenin eikä eloperäisillä mailla koboltin suhteen.

Raiheinä otti booria yhtä paljon hiesumaista kuin savimaistakin,vaikka hiesumaiden booritaso oli alhaisempi. Savimaissa kasvaneen raiheinän kobolttipitoisuus nousi selvästi korkeammaksi kuin hiesumaissa kasvaneen. Kuparia raiheinä sai yhtä paljon karkeista kivennäismaista kuin eloperäisistä maista, vaikka eloperäisten maiden kuparipitoisuus oli kaksinkertainen kivennäismaihin nähden. Eloperäisissä maissa kasvaneen raiheinän mangaanipitoisuus oli yhtä korkea kuin savimaissa kasvaneen, vaikka eloperäisten maiden mangaanipitoisuus oli vain puolet savimaiden mangaanipitoisuudesta. Sinkkiä raiheinä otti hiesumaista miltei yhtä paljon kuin muistakin maista, siitä huolimatta että sen pitoisuus oli hiesumaissa huomattavasti alhaisempi.

Tulosten mukaan hapanammoniumasetaatti + EDTA -menetelmällä uuttuvat hivenravinnemäärät kuvaavat hyvin raiheinän hivenravinteiden saantia, ja täten menetelmä sopii käytännön hivenainemäärityksiin. Maan ja kasvin pitoisuuksien eri tasot maalajiryhmissä viittaavat siihen, että samantapainen maalajiryhmitys kuin pääravinteiden tulkinnassa, olisi tarpeen myös hivenravinteiden tulkintaa esitettäessä. 